NBER WORKING PAPER SERIES

\title{
ECONOMIC EFFECTS OF CURRENCY UNIONS
}

\author{
Silvana Tenreyro \\ Robert J. Barro \\ Working Paper 9435 \\ http://www.nber.org/papers/w9435 \\ NATIONAL BUREAU OF ECONOMIC RESEARCH \\ 1050 Massachusetts Avenue \\ Cambridge, MA 02138 \\ January 2003
}

We are grateful to Alberto Alesina, Francesco Caselli, Doireann Fitzgerald, Kenneth Rogo., Andy Rose and Jeffrey Wurgler. This research has been supported, in part, by a grant from the National Science Foundation. The views in this paper are solely the responsibility of the author and should not be interpreted as reflecting the views of the Federal Reserve Bank of Boston or of the Federal Reserve System. The views expressed herein are those of the authors and not necessarily those of the National Bureau of Economic Research.

(C) 2003 by Silvana Tenreyro and Robert J. Barro. All rights reserved. Short sections of text not to exceed two paragraphs, may be quoted without explicit permission provided that full credit including, (C) notice, is given to the source. 
Economic Effects of Currency Unions

Silvan Tenreyro and Robert J. Barro

NBER Working Paper No. 9435

January 2003

JEL No. F4, F1

\section{ABSTRACT}

This paper develops a new instrumental-variable (IV) approach to estimate the effects of different exchange rate regimes on bilateral outcomes. The basic idea is that the characteristics of the exchange rate regime between two countries (exchange rate variability, fixed or float, autonomous or common currencies) are partially related to the independent decisions of these countries to peg - explicitly or de facto — to a third currency, notably that of a main anchor. Our approach is to use this component of the exchange rate regime as an IV in regressions of bilateral outcomes. We illustrate the methodology with one specific application: the economic e.ects of currency unions. The likelihood that two countries independently adopt the currency of the same anchor country is used as an instrument for whether they share or not a common currency. Three findings stand out. First, sharing a common currency enhances trade supporting previous work by Rose [2000]. Second, a common currency increases price co-movements; this finding is consistent with the observation that a large part of the variation in real exchange rates is caused by fluctuations in nominal exchange rates. Finally, a common currency decreases the co-movement of shocks to real GDP. This is consistent with the view that currency unions lead to greater specialization.

Silvana Tenreyro

Federal Reserve Bank of Boston
Robert J. Barro

Department of Economics

Littauer 218

Harvard University

Cambridge, MA 02138

and NBER

rbarro@harvard.edu 


\section{Introduction}

A vast empirical literature in international finance investigates the effects of exchange rate regimes on different economic outcomes. For example, several studies have analyzed the effect of exchange rate variability on bilateral trade, foreign direct investment and relative prices. Other studies have focused on the differential effects of pegged-versus-fixed exchange rates (including stricter forms of fixed-exchange rate regimes, such us currency boards or currency unions). The underlying assumption in most studies is that exchange rate regimes are randomly assigned and, hence, exogenous to the outcome variable under study. Standard endogeneity problems, however, can hide the true effect of exchange rate regimes in simple OLS estimates. For example, the choice of exchange rate regimes might reflect omitted characteristics that can also influence the economic outcome. Similarly, the adoption of a certain regime might come with other (unmeasured) policies that also affect the outcome.

The first contribution of this paper is to develop an instrumental-variable (IV) approach to address the endogeneity problem present in the estimation of the effects of exchange rate regimes on economic variables, such as bilateral capital flows, trade volumes, and comovement of business cycles. As an illustration, consider two countries that exhibit a low extent of exchange rate variability between them. There are several reasons for this low variability. Some reasons might be related to the deliberate decision of facilitating trade between the two countries, leading to a bias in OLS estimates of the effect of exchange rate variability on the volume of bilateral trade. ${ }^{1}$ Another reason, however, might be related to

\footnotetext{
${ }^{1}$ Typically, two countries that want to foster trade between themselves will also be more likely to undertake other steps, such as reduction of bilateral tariff and non-tariff barriers. To the extent that these steps cannot be measured in the data, an OLS estimation will attribute all the credit to the low variability.
} 
the independent decisions of these two countries to keep a close parity with a third country's currency. In this case, the level of exchange rate variability between the two countries will be exogenous to their bilateral trade. The methodology proposed in this study exploits this triangular relationship with third countries to identify the economic effect of different exchange rate regimes or features of exchange rates regimes (e.g. variability) on bilateral outcomes. In particular, following this example, the methodology isolates the motive for low (or high) variability that relates to the objective of pegging to a third currency and uses this motivation as an IV for the extent of variability.

While the methodology developed in this paper can be applied to the analysis of different exchange rate arrangements, we illustrate it here with one specific application: the effect of currency unions on bilateral trade and on the extent of co-movement of output shocks and price shocks.

Assessing the economic effects of currency unions is imperative, given the recent developments in international monetary arrangements. Twelve Western European countries have recently instituted the euro as their common currency. Sweden, Denmark and Britain have opted out, but they might join in the near future. Several Eastern European countries are debating the unilateral adoption of the euro as legal tender. Ecuador fully dollarized its economy; El Salvador and Guatemala legalized the use of the U.S. dollar, and other governments in South and Central America are giving serious consideration to dollarization. Six West African states have agreed to create a new common currency by the year 2003, and eleven members of the Southern African Development Community are debating whether to adopt the U.S. dollar or to create an independent monetary union possibly anchored to the 
South African rand. ${ }^{2}$ Finally, six oil-producing countries have expressed their intention to form a currency union by $2010 .^{3}$

A number of recent papers estimate the effect of currency unions on bilateral trade. Most notably, Rose [2000] and Frankel and Rose [2002] report that bilateral trade between two countries that use the same currency is, controlling for other effects, over two-hundredpercent larger than bilateral trade between countries that use different currencies. The underlying assumption in these studies is that currency unions are randomly assigned. As suggested before, unmeasured characteristics might create spurious links between currencyunion status and bilateral trade. For example, compatibility in legal systems, greater cultural links, better infrastructure for bilateral transportation and tied bilateral transfers may increase the propensity to share a common currency as well as encourage trade between two countries. Similarly, countries willing to share a common currency may also take additional (unmeasured) policies to foster integration and facilitate trade. These omitted characteristics could lead to a positive bias in simple OLS estimates. Other omitted variables may cause a downward bias in OLS estimates. As an example, higher levels of monopoly distortion in a country's economy mean higher markups, which tend to deter trade. At the same time, high levels of monopoly distortion may lead to higher inflation rates under discretion and therefore increase the need to join a currency union as a commitment device to reduce inflation. ${ }^{4}$ In this paper we revisit previous estimates of the currency-union effect on trade

\footnotetext{
${ }^{2}$ The group of West African countries includes Ghana, Nigeria, Liberia, Sierra Leone, Gambia, and Guinea. Initial participants in the Southern African currency union will be South Africa, Botswana, Lesotho, Malawi, Mauritius, Mozambique, Namibia, Swaziland, Tanzania, and Zimbabwe. Zambia is expected also to confirm its membership. Angola, the Democratic Republic of Congo, and Seychelles, also members of the Southern African Development Community, will not join the monetary union.

${ }^{3}$ This group includes Saudi Arabia, United Arab Emirates, Bahrain, Oman, Qatar, and Kuwait.

${ }^{4}$ See Barro and Tenreyro [2001].
} 
using the new instrument to address the endogeneity problem.

Trade is not the only interesting outcome of currency unions. Monetary unions might also alter the extent of synchronization of shocks and the patterns of co-movement among participants. This consideration is relevant for determining the suitability of the adoption of a foreign currency or participation into currency unions: countries evaluating the decision to join or not should take into account the effect that different currency arrangements have on the patterns of co-movement. By adopting a foreign currency or forming a currency union, countries lose the independence to tailor monetary policy to local needs. If currency unions lead to higher synchronization of shocks, this change will generate greater consensus over the direction of monetary policy and reduce the cost of giving up monetary-policy independence. The opposite will be true if currency unions induce less synchronization. Hence, this paper also investigates the effects of currency unions on the patterns of co-movement of prices and real GDP shocks.

In order to construct the IV, we first estimate the probability that a given country adopts the currency of a main anchor country. The estimation of the relationship "client-anchor," in the terminology used by Alesina and Barro [2002], is interesting in its own right, as it elucidates part of the reason why countries adopt a foreign currency or join currency unions. The IV is then obtained by computing the joint probability that two countries, independently, adopt the same currency. The underlying assumption in the analysis is that there exist factors driving the decision to adopt a third country's currency that are independent of the bilateral links between two potential clients. In other words, the basic idea is to isolate the motive that relates to third countries' currencies and use this motivation as an IV for whether two 
countries do or do not share a common currency.

The main results of this study are the following. First, regarding the motivation to adopt a foreign anchor's currency, the probability of adoption increases when $i$ ) the client speaks the same language as the anchor, $i i$ ) the client is geographically closer to the anchor, $i i i$ ) the client was a former or current colony of the anchor, $i v$ ) the client is poorer in terms of GDP per capita, $v$ ) the client is smaller in terms of population size, and $v i$ ) the anchor is richer in terms of per capita GDP.

Second, the IV estimates of the impact of currency unions on bilateral trade indicate a significant positive effect, supporting previous findings by Rose [2000] and co-authors. In other words, endogeneity bias is not responsible for the large effects previously documented.

Third, while OLS estimates indicate that currency unions do not affect the extent of comovement of output shocks, the IV estimates suggest that currency unions may decrease the co-movement of output shocks. This finding is consistent with the view that currency unions enhance sectoral specialization, and shocks tend to affect sectors asymmetrically. The bias in OLS is the result of reverse causality: countries with higher co-movement are more likely to form currency unions. Finally, the co-movement of price shocks increases with currency unions, which supports the observation that a large part of the fluctuations in real exchange rates is due to fluctuations in nominal exchange rates.

The paper is organized as follows. Section 2 discusses the endogeneity problem in previous empirical analyses of currency unions. It then discusses how the IV approach can be applied to study the economic effects of different exchange rate arrangements. Section 3 studies the motivation to link the currency to a main anchor. Section 4 revisits the currency union effect 
on trade. Section 5 estimates the effects of currency unions on the extent of co-movement of prices and outputs. Section 6 summarizes and concludes.

\section{Endogeneity bias and a new IV approach}

\section{A Endogeneity}

The empirical work on the effects of currency unions (or indeed, other exchange rate arrangements) on trade has been framed within the standard "gravity equation" model. The model states that bilateral trade between a pair of countries increases with the sizes of the countries and decreases with their distance, broadly construed to include all factors that create "trade resistance." The gravity equation is then augmented with a dummy variable indicating whether or not the countries share the same currency. In his seminal paper in the area, Rose [2000] reports that bilateral trade between countries that use the same currency is over two-hundred percent larger than bilateral trade between countries with different currencies. Subsequent papers, including Frankel and Rose [2002], Rose and van Wincoop [2001], and Glick and Rose [2002], have expanded the analysis and generally confirmed the large enhancement effect of currency unions on trade. Alesina, Barro, and Tenreyro [2002] summarize and discuss these findings.

The implicit assumption in the various empirical studies is that currency unions (or, more generally, exchange rate arrangements) are randomly formed among countries. ${ }^{5}$ Standard endogeneity problems, however, can confound the estimates. For example, countries that would naturally trade more might share characteristics that tend to make them more prone

\footnotetext{
${ }^{5}$ For an exception, see Persson [2001].
} 
to form a currency union. In addition, countries that decide to join a currency union might also be more likely to foster integration through other means, for example, by encouraging the harmonization of standards to enhance competition and trade and by reducing regulatory barriers. These unmeasured characteristics-to the extent that they affect or are correlated with the propensity to share a common currency and the volume of bilateral trade-will bias OLS estimates of the currency union effect. The use of country-pair fixed effects employed in some studies may not eliminate the bias, because a shift at some point in time in trade volumes may be related to a change in the propensity to use a common currency.

\section{B A new approach}

Two countries may be motivated to share a common currency for several reasons. In order to eliminate the endogeneity bias discussed in the previous section, one needs to isolate the part of the motivation that is exogenous to the bilateral link between the two countries. As an example, consider two countries that use a common currency, say Senegal and Togo, both of which belong to the CFA franc zone. Part of the reason why they share a common currency is that both countries want to keep the French franc (now the euro) as a nominal anchor. ${ }^{6}$ However, other considerations not related to France but to the objective of promoting political and economic integration between Senegal and Togo may have influenced the decision to share a common currency. These other considerations are likely to bias OLS estimates of the effects of currency unions on trade. Hence, separating out the relation with the anchor provides an instrument to estimate the effect of sharing a common currency on

\footnotetext{
${ }^{6}$ The CFA franc has been tied, except for one devaluation, to the French franc, and the French Treasury has guaranteed the convertibility of CFA francs into French francs.
} 
bilateral trade.

Alesina and Barro [2002] provide a formal model for the anchor-client relationship in the context of the currency-union decision. The model shows that countries with lack of internal discipline for monetary policy (as revealed by a history of high and variable inflation) stand to gain more from giving up their currencies, provided that the anchor country is able to commit to sound monetary policy. This commitment is best protected when the anchor is large and the client small (otherwise, the anchor may find it advantageous to relinquish its commitment. In addition, the model shows that, under reasonable assumptions, client countries benefit more from adopting the currency of an anchor with which they would naturally trade more, that is, an anchor with which trading costs -other than the ones associated with the use of different currencies-are small. The model also predicts that small countries benefit more from giving up their currency, and the benefit increases with the size of the anchor. These features of the relation between clients and anchors are used to guide the instrumentation.

In order to construct the instrument, we use a probit analysis for all country pairings from 1960 to 1997 with six potential anchors that fit the theoretical characterization of Alesina and Barro [2002], given the countries' sizes (GDPs) and records of low and stable inflation. The group of anchors includes Australia, France, Germany, Japan, the United Kingdom, and the United States. The probit regressions include various measures of distance between clients and anchors (to proxy for trading costs) and the sizes of potential clients and anchors.

Consider a potential client country, denoted by $i$, which is evaluating the possibility of adopting the currency of one of the six anchors, denoted by $k(k=1,2, \ldots, 6)$. The probit 
regression determines the estimated probability $p(i, k, t)$ that client $i$ adopts the currency of anchor $k$ at time $t$. If the clients adopt an anchor currency independently, then the joint probability that countries $i$ and $j$ use the currency of a common anchor $k$ at time $t$ is given by:

$$
J^{k}(i, j, t)=p(i, k, t) * p(j, k, t) .
$$

The probability $J^{k}(i, j, t)$ will be high if both countries are "close enough" to the potential anchor $k$. The joint probability that, at time $t$, countries $i$ and $j$ use the same foreign currency (among the six candidates considered in this analysis) ${ }^{7}$ is given by the sum of the joint probabilities over the support of potential anchors: ${ }^{8}$

$$
J(i, j, t)=\sum_{k=1}^{6} J^{k}(i, j, t)=\sum_{k=1}^{6} p(i, k, t) * p(j, k, t) .
$$

The variable $J(i, j, t)$ can be used as an instrument for the currency-union dummy in the regressions for bilateral trade and co-movements. The underlying assumption for the validity of the instrument is that the bilateral trade between countries $i$ and $j$ depends on gravity variables for countries $i$ and $j$, but not on gravity variables involving third countries, notably the potential anchors. Gravity variables involving third countries affect the likelihood that the clients $i$ and $j$ share a common currency and thereby influence bilateral trade and co-

\footnotetext{
${ }^{7}$ This approach neglects the possibility that country $i$ chooses the infeasible outcome of linking simultaneously with more than one of the anchors $k$. We could modify the analysis to rule out these outcomes. However, the results would not be affected, because the probability of choosing two anchors simultaneously is negligible, given that each individual probability is itself small.

${ }^{8}$ For a pair of anchors, say, $k_{1}$ and $k_{2}$, the probability is

$J\left(k_{1}, k_{2}, t\right)=p\left(k_{1}, k_{2}, t\right) *\left[1-\sum_{s=3}^{6} p\left(k_{1}, k_{s}, t\right)\right]+p\left(k_{1}, k_{2}, t\right) *\left[1-\sum_{s=3}^{6} p\left(k_{2}, k_{s}, t\right)\right]+\sum_{s=3}^{6}\left[p\left(k_{1}, k_{s}, t\right) * p\left(k_{2}, k_{s}, t\right)\right]$
} 
movements between $i$ and $j$ through that channel. The assumption requires that these variables not influence the bilateral trade or the extent of co-movement between $i$ and $j$ through other channels.

As mentioned in the introduction, the endogeneity problem is pervasive in the literature studying the economic effects of exchange rate arrangements. Although this study focuses on the economic effects of currency unions, the methodology can also be applied to the study of different exchange rate arrangements. For example, consider the problem of estimating the effect of nominal-exchange rate variability on bilateral trade (or any other bilateral outcome for which exchange rates cannot be considered exogenous). One could, in principle, isolate the part of the exchange-rate variability that relates to the independent decision to peg (explicitly or de facto) to a low-inflation currency to overcome the lack of discipline in monetary policy. ${ }^{9}$ In this context, one could instrument the extent of variability between two countries using the likelihood that two countries independently target the exchange rate of a common nominal anchor.

\section{Determinants of currency unions: The anchor-client} relationship

The results of the probit regressions are in Table 2. The sample consists of all country pairs that include the six candidate anchors: Australia, France, Germany, Japan, U.K., and U.S. The data come from Glick and Rose [2002], except for real GDP per capita and population,

\footnotetext{
${ }^{9}$ The form of the peg-and, hence, the dividing line for whether a country is a fixer or a floater-can vary. Crawling pegs, fixed exchange rates with bands of different widths, currency boards, and currency unions are illustrations of the range of options.
} 
which come from the World Bank's World Development Indicators. The equations are for annual data, include year effects, and allow for clustering over time for country pairs. The dependent variable is based on countries sharing a common currency. ${ }^{10}$ The independent variables, as mentioned before, are motivated by the model of currency-union decision formulated by Alesina and Barro [2002]. We include various measures of distance that are typically included in the gravity equation literature, and different measures of size for both the anchor and the client. Summary statistics for the data used in the probit equation are presented in Table 1, Panel B.

The first two columns in Table 2 show the estimated coefficients and their corresponding (clustered) standard errors. The third column shows the marginal effects evaluated at the mean values of all variables. Since in this sample only 3.4 percent of the pairs share a common currency, evaluating the effects at the mean is almost equivalent to evaluating at the mean of the sub-sample of pairs that do not share a common currency. In other words, the "mean" country in this sample is far from considering the adoption of a foreign currency. Given that the marginal effects are highly nonlinear, we also computed the marginal effects at the mean of the subsample of pairs sharing a common currency. The relevant effects for the marginal country, that is, the country that is indifferent about adopting the currency of a potential anchor, must lie somewhere in between.

Table 2 shows that the probability that a country uses the currency of one of the main

\footnotetext{
${ }^{10}$ We depart from the definition of currency unions in Glick and Rose [2002] by treating the CFA countries as in a currency union with France. The main reason to do so is because France has guaranteed free convertibility of the CFA franc into French francs (and now into euros), and the CFA franc has been tied to the French franc, except for one devaluation in 1994. The French franc and currently the euro can and do circulate in the CFA zone. Likewise, we treat the countries in the Eastern Caribbean Currency Union as in a monetary union with the United Kingdom before 1976 and with the United States after that. In both periods, they mantained a strict peg with the British pound and the American dollar, respectively.
} 
anchors at a given point in time increases when $i$ ) the client speaks the same language as the anchor, $i i$ ) the client is geographically closer to the anchor, $i i i$ ) the client was a former or current colony of the anchor, $i v$ ) the client is poorer in terms of GDP per capita, $v$ ) the client is smaller in terms of population size, and vi) the anchor is richer - among the six anchors considered- in terms of per capita GDP. Notice that the existence of regional trade agreements tends to decrease the propensity to form currency unions. ${ }^{11}$ Other geographical characteristics, such as access to land or being an island, do not seem relevant for adopting a foreign currency, once the other control variables are included.

\section{Trade}

Table 3 shows the regressions of bilateral trade on the currency-union dummy and the various gravity characteristics. The regressions use annual data from 1960 to 1997 for all pairs of countries for which data are available. The dependent variable is the logarithm of bilateral trade. $^{12}$ The variables included as controls are standard in the gravity equation literature; they comprise various measures of distance and size. ${ }^{13}$ The systems include year effects and

\footnotetext{
${ }^{11}$ One interpretation of the negative relation can be the following. Well-functioning economies are less likely to use import tariffs and seignioriage as sources of fiscal revenue. Hence, these economies will be more likely to sign free trade agreements. At the same time, a smaller need for seignioriage revenues reduces the need for commitment (because the inflationary bias stemming from the incentives to monetize budget deficit is smaller). A lower inflationary bias decreases the value of currency unions as commitment devices to temper inflation. This may explain why, in the data, countries that do not need currency unions as an external commitment are also more likely to sign regional trade agreements. Including the EMU might change this historical pattern, as countries in the EMU have previously signed free-trade agreements and most likely, the search for commitment was not the main motivation for the union.

${ }^{12}$ The logarithmic specification leaves out observations for which trade is zero. While this omission should not, in principle, bias the coefficients in any particular direction, it suggests that the standard specification used in the literature is not entirely appropriate. For comparability, we stick to the framework used in the literature. The results, however, are similar if we include the zeroes and estimate the gravity equation using $\ln ($ trade $+c)$ as the dependent variable, for small values of $c$.

${ }^{13}$ Information on bilateral trade, distance, contiguity, access to water, language, colonial relationships, regional trade agreements and currency unions comes, as before, from Glick and Rose [2002]. Data on real per capita GDP and population come from the World Bank's World Development Indicators. As already
} 
allow the error terms to be correlated over time for a given country pair. Summary statistics for the data are presented in Table 1, Panel A. The second and fourth columns include country-fixed effects, which control for remoteness and other country-specific factors that inhibit trade, as in Rose and van Wincoop [2001].

Most of the gravity variables have the expected signs: geographical proximity, common border, access to land, common language, common colonial history, and size all increase the volume of trade between two countries. When country-fixed effects are included, however, free trade agreements and population do not significantly affect trade, and the island dummies have a negative, rather than positive, effect on trade.

In the OLS system, the estimated coefficient on the currency-union dummy is 0.67 without country-fixed effects, and 0.96 with country-fixed effects. These results are consistent with Rose [2000], despite the different definition of currency union used in this study. ${ }^{14}$ In the instrumental-variable specification, the estimated effect of currency unions on bilateral trade becomes even larger: the coefficient on the dummy variable is 0.95 without country-fixed effects and 1.9 with country-fixed effects. ${ }^{15}$ Hence, the results indicate that endogeneity is not the reason for the large effects documented by Rose [2000] and co-authors. If anything, OLS underestimates the impact on bilateral trade. ${ }^{16}$ Barro and Tenreyro [2000] offer a possible explanation for the negative bias. Economies with higher degrees of monopoly distortion and

explained, the currency union dummy is modified to reflect the link between the CFA franc to the French franc and the link of the Eastern Caribbean dollar to the British pound before 1976 and the American dollar thereafter.

${ }^{14}$ The estimated effect of the currency-union dummy is larger when using Rose's stricter definition. The estimated coefficient on the currency-union dummy using Rose's definition is 0.99 , without fixed effects and 1.14 with fixed effects.

${ }^{15}$ The corresponding values, using Rose's definition of currency union, are 1.57 without country-fixed effects and 3.30 with country-fixed effects.

${ }^{16}$ The p-values from a Durbin-Wu-Hausman test, reported at the bottom of Table 4, indicate that endogeneity of the currency union variable has detrimental effects on simple OLS estimates, and the IV technique is required. 
therefore higher markups feature lower trade (lower than would be predicted by the standard gravity equation). At the same time, these economies are more likely to join currency unions to eliminate the inflationary bias stemming from the high distortion.

The trade effects are extremely large and one should exercise caution before generalizing the results. In this sample, most of the countries in currency unions are small and poor clients for which the enhancement effect on trade can be substantial (especially if they start at low levels of trade). Moreover, the logarithmic specification dictated by the theory gives a larger weight to observations with small bilateral trade volumes. Therefore, as Rose [2000] warns, the results cannot be directly extrapolated to more developed countries.

\section{Synchronization of shocks}

Currency unions might alter the extent of synchronization of shocks. Since this synchronization influences the suitability of currency adoption, a country deciding whether or not to join a union should consider the effect of the union on the patterns of co-movement. ${ }^{17} \mathrm{~A}$ positive response of co-movements to currency unions will lead to a higher level of consensus over the direction of monetary policy and will thereby reduce the cost of relinquishing an independent currency. A negative response of co-movements will have the opposite effect, generating a larger loss associated with the lack of monetary policy independence.

In this section, we investigate the effect of currency unions on the extent of co-movements of real GDP and prices. As suggested before, the response of co-movements to currency unions can be positive or negative. On the one hand, sharing a common currency eliminates

\footnotetext{
${ }^{17}$ See also Frankel and Rose [1998] for a discussion of the endogeneity of the optimum currency area criteria. They remark that the criteria for optimality of currency unions should be considered ex post.
} 
the fluctuations in relative prices driven by nominal exchange rate variation and, hence, can lead to higher price co-movement. In addition, the common monetary shocks will induce higher co-movement in consumption behavior and production decisions. On the other hand, by lowering transaction costs and eliminating exchange rate uncertainty, currency unions might lead to greater specialization. Specialization can take place within a given sector (for example, different countries producing different models of cars) or between sectors (for example, one country produces cars and the other produces agricultural goods). To the extent that shocks are sector-specific and common to all countries, the second type of specialization will lead to less co-movement of shocks. ${ }^{18}$

The standard omitted-variable problem can also arise in the estimation of the effect of currency unions on the extent of co-movement of shocks. As already mentioned, currency unions are generally accompanied by parallel efforts to promote integration. For example, two countries adopting a common currency will tend also to lower tariff and non-tariff barriers, which are poorly measured in the data. These lower regulatory barriers might increase the co-movement of shocks between two countries and, hence, simple OLS estimates will attribute too much credit to the use of a common currency.

To compute bilateral co-movement of price and output, we follow Alesina, Barro and Tenreyro [2002]. Relative prices are measured using the real exchange rate calculated from GDP deflators. The measure used is the purchasing power parity (PPP) for GDP divided by the U.S. dollar exchange rate. ${ }^{19}$ This measure indicates the price level in country $i$ relative

\footnotetext{
${ }^{18}$ Krugman [1993] formulated this argument in the context of the discussion of the potential unsustainability of the European Monetary Union.

${ }^{19} P_{i}=\frac{P P P \text { of } G D P_{i}}{E x . r a t e}$ measures how many units of U.S. output can be purchased with one unit of country $i$ 's output, that is, it measures the relative price of country $i$ 's output with respect to that of the United States. By definition, this price is always one when $i$ is the United States.
} 
to that in the United States, $P_{i, t} / P_{U S, t}$. The relative price between countries $i$ and $j$ is then computed by dividing the value for country $i$ by that for country $j$.

For every pair of countries, $(i, j)$, we use the annual time series $\left\{\ln \frac{P_{i, t}}{P_{j, t}}\right\}_{t=1960}^{t=1997}$ to compute the second-order auto-regression:

$$
\ln \frac{P_{i t}}{P_{j t}}=b_{0}+b_{1} \cdot \ln \frac{P_{i, t-1}}{P_{j, t-1}}+b_{2} \cdot \ln \frac{P_{i, t-2}}{P_{j, t-2}}+\varepsilon_{t i j} .
$$

The estimated residual, $\hat{\varepsilon}_{t i j}$, measures the part of the relative price that could not be predicted from the two prior values of relative prices. The extent of co-movement is then measured as the negative of the root-mean-squared error:

$$
C P_{i j} \equiv-\sqrt{\frac{1}{T-3} \sum_{t=1}^{T} \hat{\varepsilon}_{t i j}^{2} .}
$$

Similarly, the extent of co-movement of output comes from the estimated residuals from the second-order auto-regression on annual data for relative per capita GDP:

$$
\ln \frac{Y_{i t}}{Y_{j t}}=c_{0}+c_{1} \cdot \ln \frac{Y_{i, t-1}}{Y_{j, t-1}}+c_{2} \cdot \ln \frac{Y_{i, t-2}}{Y_{j, t-2}}+u_{t i j} .
$$

The estimated residuals, $\hat{u}_{t i j}$, measure the unpredictable movements in relative per capita output. The measure of the extent of co-movement is analogous to the one used for prices:

$$
V Y_{i j} \equiv-\sqrt{\frac{1}{T-3} \sum_{t=1}^{T} \hat{u}_{t i j}} .
$$

This measure of co-movement is more relevant from the perspective of monetary pol- 
icy than a correlation of output movements. Consider two countries $i$ and $j$ whose output movements are highly correlated but where the countries exhibit substantially different variabilities of output. Suppose that country $i$ is the one with the lower variability. In this case, the correlation of output movements will be high, but the monetary policy response desired by country $i$ will be insufficient for country $j$. In other words, a high correlation is not sufficient to ensure that the desired monetary policies are similar.. The measure of co-movement used in this paper captures more adequately the criterion for suitability.

Data on PPPs for the GDPs come from the Penn World Tables and are complemented with the World Bank's World Development Indicators when the first source is missing. Data on real per capita GDP come from the World Development Indicators.

Table 4 shows the effect of currency unions on the co-movements of prices. We include all the controls typically incorporated in gravity regressions, that is, various measures of distance and size. The logic for including the same controls is that the forces that determine trade will also affect the extent of price-arbitrage between countries. There are, however, some differences in the way that these forces can influence the outcomes. For example, countries that are close in terms of the gravity variables may be motivated to specialize in different products. In this case, nearby countries will be subject to different sectoral shocks and will likely exhibit lower co-movements of prices. In any event, it seems prudent to control for the gravity variables.

In the co-movement equations, the sample consists of one observation (estimated for the period 1960-1997) on each country pair, for pairs that have at least twenty observations. The regressors, as well as the instrumental variables, are the averages over the period. ${ }^{20}$ The

\footnotetext{
${ }^{20}$ For GDP per capita and population, we use the value in 1985 as opposed to the average, because the
} 
first two columns report the estimates generated by OLS, and the last two columns show the IV estimates. As before, the second and fourth columns include country-fixed effects.

The regressions show that price co-movement rises with regional trade agreements and falls with geographical distance. Sharing a border does not affect the co-movement, once distance is taken into account. Speaking the same language and sharing the same colonizer have positive, but small effects on co-movement. In the IV specification, these effects become negligible. An ex-colony and its colonizer tend to exhibit less co-movement of prices, possibly because colonies tended to specialize in products that were scarce in the colonizer's land. Price co-movement also rises with the various measures of country size, except for population. However, the country fixed effects capture most of the size effects-hence, these size effects become statistically insignificant.

Table 4 shows that sharing a common currency significantly increases price co-movement, with an estimated OLS coefficient of 0.062 when country-fixed effects are excluded, and 0.045 when fixed effects are included. These estimates are large relative to the mean of the comovement variable (the negative of the root mean squared error of the AR process described before) of -0.16 . The instrumental-variable regression indicates even more substantial effects than the ones generated by OLS. The estimates are 0.15 without country-fixed effects and 0.07 with fixed effects.

The p-values from a Durbin-Wu-Hausman test are reported at the bottom of Table 4 . The null hypothesis that an OLS estimator of the model would yield consistent estimates is rejected. In other words, endogeneity of the currency-union variable has detrimental effects averages are missing for some countries. Using different years for GDP or population does not alter the main results. 
on simple OLS estimates, and the IV technique is required. As mentioned before, the positive effect of currency unions on the co-movement of price shocks is most likely associated with the decrease in nominal exchange rate volatility stemming from the use of a common currency.

The co-movement of output shocks is studied in Table 5. One difference from the results on price co-movements is that the inclusion of fixed effects makes a difference in the estimated coefficients of most "distance" variables. For instance, although free-trade agreements and geographical proximity seem to increase the co-movement of outputs (columns 1 and 3) when country fixed effects are excluded, the effects become statistically insignificant when the fixed effects are added. In contrast, although sharing a border does not affect output co-movements in the specification without fixed effects, sharing a border does increase the comovement when fixed effects are included. Henceforth, we comment on the results with fixed effects, as they provide more adequate controls for remoteness and multilateral resistance.

Speaking the same language and sharing the same colonizer increase the co-movement of output, but the ex-colony-colonizer variable does not affect the extent of co-movement. Size, measured by GDP per capita and geographical area, tends to increase the co-movement. However, a rise in the population of the larger country decreases co-movement.

In the OLS estimation, the effect of currency unions on output co-movement is insignificant. However, in the instrumental-variable estimation, when fixed effects are included, the currency union effect becomes negative and significant at the ten percent level. The DurbinWu-Hausman test also prefers the IV estimator over the OLS when country fixed effects are included (the p-value is 5 percent). ${ }^{21}$

\footnotetext{
${ }^{21}$ When fixed effects are excluded, however, the Durbin-Wu-Hausman test does not reject the hypothesis of exogeneity.
} 
The negative effect of currency unions on the extent of co-movement of outputs could reflect a positive effect of currency unions on sectoral specialization, which can then lead to a decrease in the extent of co-movement, as Krugman (1993) suggested. The effect-in absolute values-is not as substantial as the one found for price co-movement: the estimated coefficient is -0.003 , whereas the mean of this variable (the negative of the root-mean-squared error described above) is -0.06 . This effect, however, might be different for developed countries forming a currency union if, for example, developed countries tend to specialize in the same industries (e.g., different industrialized countries produce different types of cars). In this case, countries will tend to be exposed to similar sectoral shocks and integration will lead to higher co-movement. ${ }^{22}$

\section{Conclusion}

This paper proposes a new instrumental variable to study the effects of different exchange rate arrangements on economic outcomes. We apply the methodology to investigate the impact of currency unions on bilateral trade and the extent of co-movements of prices and outputs. The instrument relies on the idea that one reason why two countries share a common currency is the attractiveness of a third country's currency as an anchor. The validity of the instrument requires that the motivation to adopt an external anchor's currency is exogenous to the bilateral link between two potential client-countries. The paper shows that the probability that a client adopts the currency of a main anchor increases when the client is geographically close, speaks the same language, and shares a colonial relationship with the anchor. It also

\footnotetext{
${ }^{22}$ See Frankel and Rose [1998] for a study on the relationship between trade and business cycles using OECD countries.
} 
increases when the client is smaller and poorer and when the anchor is richer. The likelihood that two countries share a common currency is calculated from the probability that each of them, independently, uses the currency of a third country. This likelihood serves as an instrument for the common currency dummy in the estimation of the economic effects of monetary unions.

The IV approach is used to revisit the effect of currency unions on trade and to investigate the effect of currency unions on the extent of co-movement of prices and outputs. Three main findings follow. First, currency unions significantly increase bilateral trade, a result consistent with previous findings by Rose [2000] and co-authors. This finding suggests that the large trade effect found previously for currency unions is not due to endogeneity bias. Second, currency unions significantly increase the extent of price co-movement. This response most likely reflects the elimination of nominal exchange rate volatility. Third, the IV results suggest that currency unions might decrease the extent of co-movement of output, possibly as a consequence of higher sectoral specialization. Simple OLS estimation, however, fails to reveal this negative relationship. 


\section{References}

[1] Alesina, Alberto and Robert J. Barro (2002). "Currency Unions," Quarterly Journal of Economics, May, 409-436.

[2] Alesina, Alberto, Robert J. Barro, and Silvana Tenreyro (2002). "Optimum Currency Unions," forthcoming, NBER Macroeconomic Annual.

[3] Anderson, James and Eric van Wincoop (2001). "Borders, Trade and Welfare," forthcoming, Brookings Trade Forum 2001.

[4] Barro, Robert J. and David B. Gordon (1983). "Rules, Discretion, and Reputation in a Model of Monetary Policy," Journal of Monetary Economics, July, 101-121.

[5] Barro, Robert J. and Silvana Tenreyro (2000). "Closed and Open Economy Models of Business Cycles with Marked-Up and Sticky Prices," NBER Working Paper no. 8043, December.

[6] Frankel, Jeffrey and Andrew Rose (2002). "An Estimate of the Effect of Currency Unions on Trade and Income," forthcoming, Quarterly Journal of Economics.

[7] Frankel, Jeffrey and Andrew Rose (1998). "The Endogeneity of the Optimum Currency Area Criteria," Economic Journal, July, 1009-1025.

[8] Glick, Reuben and Andrew Rose (2002). "Does a Currency Union Affect Trade? The Time Series Evidence," forthcoming, European Economic Review. 
[9] Krugman, Paul (1993). "Lessons of Massachusetts for EMU," in F. Torres and F. Giavazzi (eds.), Adjustment and Growth in the European Monetary Union, Cambridge, Cambridge University Press.

[10] Persson, Torsten (2001). "Currency Union and Trade, How Large Is the Treatment Effect?" Economic Policy, 335-48.

[11] Rose, Andrew (2000). "One Money One Market: Estimating the Effect of Common Currencies on Trade," Economic Policy.

[12] Rose, Andrew and Eric van Wincoop (2001). "National Money as a Barrier to International Trade: The Real Case for Currency Union," American Economic Review, May, 386-90. 
Table 1

Panel A. Summary Statistics. Whole Sample

\begin{tabular}{lrr}
\hline \hline Variable & Mean & Std. Dev \\
\hline Log of Trade & 9.949 & 3.543 \\
Currency union & 0.022 & 0.147 \\
Regional trade agreement & 0.016 & 0.124 \\
Log of distance & 8.199 & 0.826 \\
Contiguity dummy & 0.026 & 0.158 \\
One landlocked country in pair dummy & 0.206 & 0.405 \\
Two landlocked countries in pair dummy & 0.014 & 0.116 \\
One island in pair dummy & 0.290 & 0.454 \\
Two islands in pair dummy & 0.038 & 0.191 \\
Common language dummy & 0.215 & 0.411 \\
Ex-colony-colonizer dummy & 0.021 & 0.143 \\
Common colonizer dummy & 0.094 & 0.291 \\
Current colony (or territory) dummy & 0.002 & 0.041 \\
Min(log of per capita GDP in pair) & 6.958 & 1.277 \\
Max(log of per capita GDP in pair) & 8.880 & 1.253 \\
Min(log of population in pair) & 14.727 & 1.643 \\
Min(log of area in pair) & 16.974 & 1.495 \\
Min(log of area in pair) & 10.533 & 2.339 \\
Max(log of area in pair) & 13.204 & 1.731 \\
Year & 83.203 & 10.189 \\
\hline Co-movement of output shocks & -0.061 & 0.023 \\
Co-movement of price shocks & -0.156 & 0.090 \\
\hline \hline
\end{tabular}

$\mathrm{N}=185,580$ except for co-movement of output shocks $(\mathrm{N}=6,923)$ and price shocks $(\mathrm{N}=7,218)$. See notes of tables 3 and 4 . 
Table 1 (continued)

Panel B. Summary Statistics. Anchor-Client Subsample

\begin{tabular}{lrr}
\hline \hline Variable & Mean & \multicolumn{1}{c}{ Std. Dev } \\
\hline Currency union & 0.034 & 0.180 \\
Regional trade agreement & 0.028 & 0.166 \\
Log of distance & 8.371 & 0.775 \\
Contiguity dummy & 0.022 & 0.146 \\
One landlocked country in pair dummy & 0.173 & 0.378 \\
Two landlocked countries in pair dummy & 0.000 & 0.000 \\
One island in pair dummy & 0.402 & 0.490 \\
Two islands in pair dummy & 0.066 & 0.249 \\
Common language dummy & 0.209 & 0.407 \\
Ex-colony-colonizer dummy & 0.090 & 0.286 \\
Current colony (or territory) dummy & 0.041 & 0.104 \\
Min(log of per capita GDP in pair) & 7.488 & 1.479 \\
Max(log of per capita GDP in pair) & 9.915 & 0.349 \\
Min(log of population in pair) & 15.155 & 1.850 \\
Min(log of area in pair) & 18.116 & 0.854 \\
Min(log of area in pair) & 11.192 & 2.261 \\
Max(log of area in pair) & 14.142 & 1.522 \\
Year & 80.772 & 10.825 \\
\hline \hline
\end{tabular}

$\mathrm{N}=29,988$. This sample includes all country pairings from 1960 to 1997 that include one of the six anchors considered in the study. 
Table 2

Propensity to Adopt the Currency of Main Anchors

\begin{tabular}{lcccc}
\hline \hline & Coefficient & Std. Error & $\begin{array}{c}\text { Marginal } \\
\text { Effect at } \\
\text { Mean }\end{array}$ & $\begin{array}{c}\text { Marginal } \\
\text { Effect at } \\
\text { Mean for } \\
\text { CU=1 }\end{array}$ \\
\hline Regional trade agreement dummy & $-0.650^{* *}$ & 0.329 & -0.0002 & -0.211 \\
Log of distance (km) & $-1.152^{* * *}$ & 0.202 & -0.0010 & -0.439 \\
Contiguity dummy & $-1.748^{* *}$ & 0.698 & 0.0000 & -0.372 \\
Landlocked client dummy & -0.499 & 0.338 & 0.0000 & -0.177 \\
One island in pair dummy & -0.262 & 0.317 & 0.0000 & -0.098 \\
Two islands in pair dummy & 0.402 & 0.375 & 0.0010 & 0.158 \\
Common language dummy & $1.136^{* * *}$ & 0.306 & 0.0040 & 0.346 \\
Ex-colony-colonizer dummy & $2.217^{* * *}$ & 0.262 & 0.0660 & 0.627 \\
Current colony (or territory) dummy & 0.520 & 0.384 & 0.0010 & 0.204 \\
Min (log-per capita GDPs in pair ) & $-0.331^{* * *}$ & 0.088 & -0.0003 & -0.126 \\
Max (log-per capita GDPs in pair ) & $1.907^{* * *}$ & 0.456 & 0.0020 & 0.727 \\
Min (log-populations in pair ) & $-0.385^{* * *}$ & 0.086 & -0.0003 & -0.147 \\
Max (log-populations in pair ) & 0.111 & 0.147 & 0.0000 & 0.042 \\
Min (log-areas in pair ) & 0.021 & 0.070 & 0.0000 & 0.008 \\
Max (log-areas in pair ) & $0.355^{* * *}$ & 0.067 & 0.0003 & 0.135 \\
\hline Observations & 29988 & & & \\
Pseudo R-squared & 0.56 & & & \\
\hline
\end{tabular}

Note: The sample consists of country-pairs that include the six candidate anchors: Australia, France, Germany, Japan, UK, and US. The equations are for annual data, include year effects, and allow for clustering over time for country pairs. Clustered standard errors are shown in the second column. The definition of currency union treats the CFA franc countries as linked to France and treats the ECCA countries as linked to the US since 1976 and to the UK before 1976. The mean of the currency-union dummy for this sample is 0.034 . The third column shows the marginal effect, evaluated at the sample mean, of each explanatory variable on the estimated probability of a currency union. The fourth column shows the marginal effects evaluated at the mean of the subsample of countries in currency unions. For dummy variables, the effect refers to a shift from zero to one.* significant at $10 \%$; ** significant at $5 \% ; * * *$ significant at $1 \%$. 
Table 3

Bilateral Trade

\begin{tabular}{|c|c|c|c|c|}
\hline & OLS & OLS & IV & IV \\
\hline Currency union & $\begin{array}{c}0.671 * * \\
(0.112)\end{array}$ & $\begin{array}{c}0.962 * * \\
(0.113)\end{array}$ & $\begin{array}{c}0.954 * * \\
(0.235)\end{array}$ & $\begin{array}{c}1.912 * * \\
(0.251)\end{array}$ \\
\hline Regional trade agreement & $\begin{array}{c}0.450 * * \\
(0.157)\end{array}$ & $\begin{array}{c}0.085 \\
(0.177)\end{array}$ & $\begin{array}{c}0.450 * * \\
(0.159)\end{array}$ & $\begin{array}{c}0.100 \\
(0.179)\end{array}$ \\
\hline Log of distance & $\begin{array}{c}-1.147 * * \\
(0.023)\end{array}$ & $\begin{array}{c}-1.311 * * \\
(0.024)\end{array}$ & $\begin{array}{c}-1.142 * * \\
(0.024)\end{array}$ & $\begin{array}{r}-1.294 * * \\
(0.024)\end{array}$ \\
\hline Contiguity dummy & $\begin{array}{c}0.568 * * \\
(0.131)\end{array}$ & $\begin{array}{c}0.366^{* *} \\
(0.133)\end{array}$ & $\begin{array}{c}0.565 * * \\
(0.131)\end{array}$ & $\begin{array}{c}0.372 * * \\
(0.131)\end{array}$ \\
\hline One landlocked country in pair dummy & $\begin{array}{c}-0.596 * * \\
(0.040)\end{array}$ & $\begin{array}{c}-2.403 * * \\
(0.402)\end{array}$ & $\begin{array}{c}-0.598 * * \\
(0.040)\end{array}$ & $\begin{array}{c}-2.496 * * \\
(0.401)\end{array}$ \\
\hline Two landlocked countries in pair dummy & $\begin{array}{c}-0.699 * * \\
(0.116)\end{array}$ & $\begin{array}{c}-4.277 * * \\
(0.808)\end{array}$ & $\begin{array}{c}-0.700 * * \\
(0.116)\end{array}$ & $\begin{array}{c}-4.458 * * \\
(0.806)\end{array}$ \\
\hline One island in pair dummy & $\begin{array}{c}-0.011 \\
(0.044)\end{array}$ & $\begin{array}{c}-1.807 * * \\
(0.487)\end{array}$ & $\begin{array}{l}-0.010 \\
(0.044)\end{array}$ & $\begin{array}{c}-2.766^{* *} \\
(0.566)\end{array}$ \\
\hline Two islands in pair dummy & $\begin{array}{c}0.682 * * \\
(0.108)\end{array}$ & $\begin{array}{c}-2.923 * * \\
(0.969)\end{array}$ & $\begin{array}{c}0.680 * * \\
(0.109)\end{array}$ & $\begin{array}{c}-4.843 * * \\
(1.128)\end{array}$ \\
\hline Common language dummy & $\begin{array}{c}0.447 * * \\
(0.046)\end{array}$ & $\begin{array}{c}0.296 * * \\
(0.047)\end{array}$ & $\begin{array}{c}0.437 * * \\
(0.046)\end{array}$ & $\begin{array}{c}0.257 * * \\
(0.048)\end{array}$ \\
\hline Common colonizer dummy & $\begin{array}{c}0.850 * * \\
(0.075)\end{array}$ & $\begin{array}{c}0.650 * * \\
(0.071)\end{array}$ & $\begin{array}{c}0.817 * * \\
(0.082)\end{array}$ & $\begin{array}{c}0.533 * * \\
(0.076)\end{array}$ \\
\hline Ex-colony-colonizer dummy & $\begin{array}{l}1.174 * * \\
(0.132)\end{array}$ & $\begin{array}{l}1.290 * * \\
(0.128)\end{array}$ & $\begin{array}{l}1.135 * * \\
(0.141)\end{array}$ & $\begin{array}{l}1.165 * * \\
(0.134)\end{array}$ \\
\hline Current colony (or territory) dummy & $\begin{array}{l}1.317 * * \\
(0.195)\end{array}$ & $\begin{array}{c}1.388 * * \\
(0.318)\end{array}$ & $\begin{array}{c}1.263 * * \\
(0.189)\end{array}$ & $\begin{array}{l}1.225 * * \\
(0.306)\end{array}$ \\
\hline Min(log of per capita GDP in pair) & $\begin{array}{c}0.908 * * \\
(0.014)\end{array}$ & $\begin{array}{c}1.156 * * \\
(0.036)\end{array}$ & $\begin{array}{c}0.908 * * \\
(0.014)\end{array}$ & $\begin{array}{c}1.146^{* *} \\
(0.036)\end{array}$ \\
\hline Max(log of per capita GDP in pair) & $\begin{array}{l}1.072 * * \\
(0.016)\end{array}$ & $\begin{array}{l}1.185 * * \\
(0.039)\end{array}$ & $\begin{array}{l}1.073 * * \\
(0.016)\end{array}$ & $\begin{array}{c}1.178 * * \\
(0.039)\end{array}$ \\
\hline $\operatorname{Min}(\log$ of population in pair) & $\begin{array}{c}0.978 * * \\
(0.014)\end{array}$ & $\begin{array}{l}-0.054 \\
(0.066)\end{array}$ & $\begin{array}{c}0.980 * * \\
(0.014)\end{array}$ & $\begin{array}{l}-0.043 \\
(0.066)\end{array}$ \\
\hline $\operatorname{Max}(\log$ of population in pair) & $\begin{array}{l}0.955 * * \\
(0.016)\end{array}$ & $\begin{array}{l}-0.088 \\
(0.068)\end{array}$ & $\begin{array}{c}0.957 * * \\
(0.016)\end{array}$ & $\begin{array}{l}-0.065 \\
(0.068)\end{array}$ \\
\hline $\operatorname{Min}(\log$ of area in pair) & $\begin{array}{c}-0.047 * * \\
(0.011)\end{array}$ & $\begin{array}{c}0.196 * * \\
(0.042)\end{array}$ & $\begin{array}{c}-0.048 * * \\
(0.011)\end{array}$ & $\begin{array}{c}0.200 * * \\
(0.042)\end{array}$ \\
\hline $\operatorname{Max}(\log$ of area in pair) & $\begin{array}{c}-0.064 * * \\
(0.013)\end{array}$ & $\begin{array}{c}0.170 * * \\
(0.037)\end{array}$ & $\begin{array}{c}-0.065^{* *} \\
(0.013)\end{array}$ & $\begin{array}{l}0.171 * * \\
(0.037)\end{array}$ \\
\hline Country fixed effects & No & Yes & No & Yes \\
\hline Observations & 185580 & 185580 & 185580 & 185580 \\
\hline $\begin{array}{l}\text { R-squared } \\
\text { Durbin-Wu-Hausman test of Exogeneity, p-value }\end{array}$ & 0.66 & 0.71 & $\begin{array}{c}0.66 \\
0.150\end{array}$ & $\begin{array}{c}0.71 \\
0.000\end{array}$ \\
\hline
\end{tabular}

Note: The equations use annual data from 1960 to 1997, include year effects, and allow for clustering of the error terms over time for country pairs. The dependent variable is $\ln$ (trade). The definition of currency union treats the CFA franc countries as linked to France and the ECCA countries as linked to the UK before 1976 and to the US after 1976. Country effects refer to each member of the pair (not to a country pair). The IV is described in the text. * Significant at $10 \%$;* significant at $5 \%$; *** significant at $1 \%$. 
Table 4

Co-movement of Price Shocks

\begin{tabular}{|c|c|c|c|c|}
\hline & OLS & OLS & IV & IV \\
\hline Currency union & $\begin{array}{c}0.0621^{* * *} \\
(0.0055)\end{array}$ & $\begin{array}{c}0.0454^{* * *} \\
(0.0027)\end{array}$ & $\begin{array}{c}0.1483^{* * *} \\
(0.0142)\end{array}$ & $\begin{array}{c}0.0691^{* * *} \\
(0.0052)\end{array}$ \\
\hline Regional trade agreement & $\begin{array}{l}0.0100 \\
(0.0200)\end{array}$ & $\begin{array}{c}0.0175^{* * *} \\
(0.0045)\end{array}$ & $\begin{array}{l}0.0118 \\
(0.0200)\end{array}$ & $\begin{array}{c}0.0183 * * * \\
(0.0045)\end{array}$ \\
\hline Log of distance & $\begin{array}{c}-0.0036^{* *} \\
(0.0020)\end{array}$ & $\begin{array}{c}-0.0027^{* * *} \\
(0.0065)\end{array}$ & $\begin{array}{l}-0.0010 \\
(0.0018)\end{array}$ & $\begin{array}{c}-0.0021 * * * \\
(0.0007)\end{array}$ \\
\hline Contiguity dummy & $\begin{array}{l}-0.0038 \\
(0.0076)\end{array}$ & $\begin{array}{l}0.0042 * \\
(0.0023)\end{array}$ & $\begin{array}{l}-0.0066 \\
(0.0078)\end{array}$ & $\begin{array}{c}0.0036 \\
(0.0023)\end{array}$ \\
\hline One landlocked country in pair dummy & $\begin{array}{c}0.0144 * * * \\
(0.0024)\end{array}$ & $\begin{array}{c}0.0166 * * * \\
(0.0021)\end{array}$ & $\begin{array}{c}0.0146 * * * \\
(0.0023)\end{array}$ & $\begin{array}{c}0.0160 * * * \\
(0.0020)\end{array}$ \\
\hline Two landlocked countries in pair dummy & $\begin{array}{c}0.0290 * * * \\
(0.0059)\end{array}$ & $\begin{array}{c}0.0325^{* * *} \\
(0.0042)\end{array}$ & $\begin{array}{c}0.0285^{* * *} \\
(0.0060)\end{array}$ & $\begin{array}{c}0.0303 * * * \\
(0.0040)\end{array}$ \\
\hline One island in pair dummy & $\begin{array}{c}0.0176 * * * \\
(0.0026)\end{array}$ & $\begin{array}{c}0.0139 * * * \\
(0.0033)\end{array}$ & $\begin{array}{c}0.0173 * * * \\
(0.0027)\end{array}$ & $\begin{array}{c}0.0127 * * * \\
(0.0030)\end{array}$ \\
\hline Two islands in pair dummy & $\begin{array}{c}0.0431 * * * \\
(0.0040)\end{array}$ & $\begin{array}{c}0.0353 * * * \\
(0.0064)\end{array}$ & $\begin{array}{c}0.0430^{* * *} \\
(0.0042)\end{array}$ & $\begin{array}{c}0.0331^{* * *} \\
(0.0064)\end{array}$ \\
\hline Common language dummy & $\begin{array}{c}0.0056^{* *} \\
(0.0024)\end{array}$ & $\begin{array}{c}0.0021^{* *} \\
(0.0009)\end{array}$ & $\begin{array}{l}0.0032 \\
(0.0025)\end{array}$ & $\begin{array}{l}0.0012 \\
(0.0009)\end{array}$ \\
\hline Common colonizer dummy & $\begin{array}{l}0.0090^{* *} \\
(0.0036)\end{array}$ & $\begin{array}{c}0.0030^{* *} \\
(0.0014)\end{array}$ & $\begin{array}{l}-0.0037 \\
(0.0044)\end{array}$ & $\begin{array}{l}-0.0009 \\
(0.0017)\end{array}$ \\
\hline Ex-colony-colonizer dummy & $\begin{array}{l}-0.0022 \\
(0.0074)\end{array}$ & $\begin{array}{l}-0.0075 \\
(0.0020)\end{array}$ & $\begin{array}{l}-0.0182 \\
(0.0088)\end{array}$ & $\begin{array}{c}-0.0115^{* * *} \\
(0.0024)\end{array}$ \\
\hline Current colony (or territory) dummy & $\begin{array}{l}0.0234 \\
(0.0197)\end{array}$ & $\begin{array}{l}0.0196^{*} \\
(0.0115)\end{array}$ & $\begin{array}{l}0.0257 \\
(0.0254)\end{array}$ & $\begin{array}{l}0.0198 \\
(0.0127)\end{array}$ \\
\hline $\operatorname{Min}(\log$ of per capita GDP in pair) & $\begin{array}{c}0.0181 * * * \\
(0.0007)\end{array}$ & $\begin{array}{c}0.0089 * * * \\
(0.0005)\end{array}$ & $\begin{array}{c}0.0184 * * * \\
(0.0008)\end{array}$ & $\begin{array}{c}0.0091 * * * \\
(0.0055)\end{array}$ \\
\hline $\operatorname{Max}(\log$ of per capita GDP in pair) & $\begin{array}{c}0.0118^{* * *} \\
(0.0009)\end{array}$ & $\begin{array}{l}0.0007 \\
(0.0005)\end{array}$ & $\begin{array}{c}0.0120 * * * \\
(0.0005)\end{array}$ & $\begin{array}{l}0.0089 \\
(0.0055)\end{array}$ \\
\hline $\operatorname{Min}(\log$ of population in pair) & $\begin{array}{c}-0.0054^{* * *} \\
(0.0010)\end{array}$ & $\begin{array}{l}-0.0010 \\
(0.0009)\end{array}$ & $\begin{array}{c}-0.0052 * * * \\
(0.0010)\end{array}$ & $\begin{array}{l}-0.0007 \\
(0.0009)\end{array}$ \\
\hline $\operatorname{Max}(\log$ of population in pair) & $\begin{array}{l}0.0004 \\
(0.0010)\end{array}$ & $\begin{array}{l}-0.0010 \\
(0.0007)\end{array}$ & $\begin{array}{c}0.0009 \\
(0.0010)\end{array}$ & $\begin{array}{l}-0.0005 \\
(0.0010)\end{array}$ \\
\hline $\operatorname{Min}(\log$ of area in pair) & $\begin{array}{c}0.0060 * * * \\
(0.0008)\end{array}$ & $\begin{array}{l}0.0010 \\
(0.0010)\end{array}$ & $\begin{array}{c}0.0057 * * * \\
(0.0008)\end{array}$ & $\begin{array}{l}0.0010 \\
(0.0007)\end{array}$ \\
\hline $\operatorname{Max}(\log$ of area in pair $)$ & $\begin{array}{c}0.0041^{* * *} \\
(0.0010) \\
\end{array}$ & $\begin{array}{l}0.0012 \\
(0.0008) \\
\end{array}$ & $\begin{array}{c}0.0036^{* * *} \\
(0.0010) \\
\end{array}$ & $\begin{array}{l}0.0010 \\
(0.0009) \\
\end{array}$ \\
\hline Country fixed effects & No & Yes & No & Yes \\
\hline Observations & 7218 & 7218 & 7218 & 7218 \\
\hline R-squared & 0.16 & 0.93 & 0.15 & 0.93 \\
\hline Durbin-Wu-Hausman test of Exogeneity, p-value & & & 0.000 & 0.000 \\
\hline
\end{tabular}

Note: Co-movements are calculated for the period 1960-1997 as indicated in the text. The regressions include only pairs of countries with 20 or more observations of relative prices. Per capita GDP and population correspond to the year 1985. The remaining explanatory variables refer to the averages over the period. Robust standard errors are in parentheses. * Significant at 10\%; ** significant at 5\%; *** significant at $1 \%$. 
Table 5

Co-movement of Output Shocks

\begin{tabular}{|c|c|c|c|c|}
\hline & OLS & OLS & IV & IV \\
\hline Currency union & $\begin{array}{c}0.0037 \\
(0.0026)\end{array}$ & $\begin{array}{l}0.0000 \\
(0.0011)\end{array}$ & $\begin{array}{c}0.0018 \\
(0.0052)\end{array}$ & $\begin{array}{l}-0.0033 * \\
(0.0019)\end{array}$ \\
\hline Regional trade agreement & $\begin{array}{c}0.0268 * * * \\
(0.0027)\end{array}$ & $\begin{array}{c}0.0012 \\
(0.0013)\end{array}$ & $\begin{array}{c}0.0269 * * * \\
(0.0027)\end{array}$ & $\begin{array}{l}0.0013 \\
(0.0013)\end{array}$ \\
\hline Log of distance & $\begin{array}{c}-0.0017^{* * *} \\
(0.0004)\end{array}$ & $\begin{array}{l}-0.0003 \\
(0.0002)\end{array}$ & $\begin{array}{c}-0.0017 * * * \\
(0.0005)\end{array}$ & $\begin{array}{l}-0.0004 * \\
(0.0002)\end{array}$ \\
\hline Contiguity dummy & $\begin{array}{l}-0.0017 \\
(0.0020)\end{array}$ & $\begin{array}{c}0.0040 * * * \\
(0.0009)\end{array}$ & $\begin{array}{l}-0.0017 \\
(0.0020)\end{array}$ & $\begin{array}{c}0.0040 * * * \\
(0.0008)\end{array}$ \\
\hline One landlocked country in pair dummy & $\begin{array}{c}0.0047 * * * \\
(0.0007)\end{array}$ & $\begin{array}{c}-0.0191 * * * \\
(0.0013)\end{array}$ & $\begin{array}{c}0.0047 * * * \\
(0.0007)\end{array}$ & $\begin{array}{c}-0.0189 * * * \\
(0.0013)\end{array}$ \\
\hline Two landlocked countries in pair dummy & $\begin{array}{c}0.0082 * * * \\
(0.0020)\end{array}$ & $\begin{array}{c}-0.0388 * * * \\
(0.0025)\end{array}$ & $\begin{array}{c}0.0082^{* * *} \\
(0.0020)\end{array}$ & $\begin{array}{c}-0.0383 * * * \\
(0.0026)\end{array}$ \\
\hline One island in pair dummy & $\begin{array}{c}0.0073 * * * \\
(0.0007)\end{array}$ & $\begin{array}{c}-0.0491 * * * \\
(0.0024)\end{array}$ & $\begin{array}{c}0.0073 * * * \\
(0.0007)\end{array}$ & $\begin{array}{c}-0.0489 * * * \\
(0.0011)\end{array}$ \\
\hline Two islands in pair dummy & $\begin{array}{c}0.0131 * * * \\
(0.0019)\end{array}$ & $\begin{array}{c}-0.0980 * * * \\
(0.0023)\end{array}$ & $\begin{array}{c}0.0131 * * * \\
(0.0019)\end{array}$ & $\begin{array}{c}-0.0973 * * * \\
(0.0023)\end{array}$ \\
\hline Common language dummy & $\begin{array}{l}-0.0008 \\
(0.0009)\end{array}$ & $\begin{array}{c}0.0007 * * \\
(0.0003)\end{array}$ & $\begin{array}{l}-0.0007 \\
(0.0009)\end{array}$ & $\begin{array}{l}0.0009 * * \\
(0.0003)\end{array}$ \\
\hline Common colonizer dummy & $\begin{array}{l}-0.0021 \\
(0.0013)\end{array}$ & $\begin{array}{c}0.0021 * * * \\
(0.0005)\end{array}$ & $\begin{array}{l}-0.0019 \\
(0.0014)\end{array}$ & $\begin{array}{c}0.0026^{* * *} \\
(0.0006)\end{array}$ \\
\hline Ex-colony-colonizer dummy & $\begin{array}{l}0.0051 * * \\
(0.0021)\end{array}$ & $\begin{array}{l}-0.0007 \\
(0.0007)\end{array}$ & $\begin{array}{c}0.0053 * * \\
(0.0022)\end{array}$ & $\begin{array}{l}-0.0001 \\
(0.0007)\end{array}$ \\
\hline Current colony (or territory) dummy & $\begin{array}{l}-0.0109 \\
(0.0111)\end{array}$ & $\begin{array}{l}-0.0024 \\
(0.0023)\end{array}$ & $\begin{array}{l}-0.0108 \\
(0.0110)\end{array}$ & $\begin{array}{l}-0.0022 \\
(0.0002)\end{array}$ \\
\hline $\operatorname{Min}(\log$ of per capita GDP in pair) & $\begin{array}{c}0.0044 * * * \\
(0.0003)\end{array}$ & $\begin{array}{c}0.0152 * * * \\
(0.0002)\end{array}$ & $\begin{array}{c}0.0044 * * * \\
(0.0003)\end{array}$ & $\begin{array}{c}0.0152 * * * \\
(0.0002)\end{array}$ \\
\hline $\operatorname{Max}(\log$ of per capita GDP in pair) & $\begin{array}{c}0.0029 * * * \\
(0.0003)\end{array}$ & $\begin{array}{c}0.0139 * * * \\
(0.0002)\end{array}$ & $\begin{array}{c}0.0029 * * * \\
(0.0003)\end{array}$ & $\begin{array}{c}0.0139 * * * \\
(0.0002)\end{array}$ \\
\hline Min(log of population in pair) & $\begin{array}{c}0.0056^{* * * *} \\
(0.0003)\end{array}$ & $\begin{array}{l}-0.0003 \\
(0.0002)\end{array}$ & $\begin{array}{c}0.0056^{* * *} \\
(0.0003)\end{array}$ & $\begin{array}{l}-0.0003 \\
(0.0002)\end{array}$ \\
\hline $\operatorname{Max}(\log$ of population in pair) & $\begin{array}{c}0.0035 * * * \\
(0.0003)\end{array}$ & $\begin{array}{c}-0.0015 * * * \\
(0.0002)\end{array}$ & $\begin{array}{c}0.0035 * * * \\
(0.0003)\end{array}$ & $\begin{array}{c}-0.0015 * * * \\
(0.0002)\end{array}$ \\
\hline Min(log of area in pair) & $\begin{array}{c}-0.0010 * * * \\
(0.0002)\end{array}$ & $\begin{array}{c}0.0088 * * * \\
(0.0002)\end{array}$ & $\begin{array}{c}-0.0010 * * * \\
(0.0002)\end{array}$ & $\begin{array}{c}0.0089 * * * \\
(0.0002)\end{array}$ \\
\hline $\operatorname{Max}(\log$ of area in pair) & $\begin{array}{c}-0.0006 * * \\
(0.0002)\end{array}$ & $\begin{array}{c}0.0090 * * * \\
(0.0003)\end{array}$ & $\begin{array}{c}-0.0006 * * \\
(0.0002)\end{array}$ & $\begin{array}{c}0.0089 * * * \\
(0.0003)\end{array}$ \\
\hline Country fixed effects & No & Yes & No & Yes \\
\hline Observations & 7610 & 7610 & 7610 & 7610 \\
\hline R-squared & 0.21 & 0.91 & 0.21 & 0.91 \\
\hline Durbin-Wu-Hausman test of Exogeneity, p-value & & & 0.760 & 0.050 \\
\hline
\end{tabular}

Note: Co-movements are calculated for the period 1960-1997 as indicated in the text. The regressions include only pairs of countries with 20 or more observations of relative output. Per capita GDP and population correspond to the year 1985. The remaining explanatory variables refer to the averages over the period. Robust standard errors are in parentheses. * Significant at $10 \%$; ** significant at $5 \%$; *** significant at $1 \%$. 